\title{
Different Thermodynamic Binding Mechanisms and Peptide Fine Specificities Associated with a Panel of Structurally Similar High- Affinity T Cell Receptors,t,
}

\author{
Lindsay L. Jones§, Leremy A. Colf $\|$, Alexander J. Bankovich $\|$, Jennifer D. Stone $\$$, Yi-Gui \\ Gao $\S$, Choi Mui Chan $\S$, Raven H. Huang $\S$, K. Christopher Garciall, $\perp$, and David M. Kranz ${ }^{\star}, \S$ \\ Department of Biochemistry and School of Chemical Sciences Biocrystallization Service, University \\ of Illinois at Urbana-Champaign, Urbana, Illinois 61801, and Howard Hughes Medical Institute and \\ Departments of Molecular and Cellular Physiology and of Structural Biology, Stanford University, \\ Stanford, California 94305
}

\begin{abstract}
To understand the mechanisms that govern T cell receptor (TCR)-peptide MHC (pMHC) binding and the role that different regions of the TCR play in affinity and antigen specificity, we have studied the TCR from T cell clone 2C. High-affinity mutants of the 2 C TCR that bind QL9- ${ }^{d}$ as a strong agonist were generated previously by site-directed mutagenesis of complementarity determining regions (CDRs) $1 \beta, 2 \alpha, 3 \alpha$, or $3 \beta$. We performed isothermal titration calorimetry to assess whether they use similar thermodynamic mechanisms to achieve high affinity for QL9- $\mathrm{L}^{\mathrm{d}}$. Four of the five TCRs examined bound to QL9- $\mathrm{L}^{\mathrm{d}}$ in an enthalpically driven, entropically unfavorable manner. In contrast, the high-affinity CDR1 $\beta$ mutant resembled the wild-type $2 \mathrm{C}$ TCR interaction, with favorable entropy. To assess fine specificity, we measured the binding and kinetics of these mutants for both QL9- $\mathrm{L}^{\mathrm{d}}$ and a single amino acid peptide variant of QL9, called QL9-Y5-L ${ }^{\mathrm{d}}$. While 2C and most of the mutants had equal or higher affinity for the Y5 variant than for QL9, mutant CDR1 $\beta$ exhibited 8-fold lower affinity for Y5 compared to QL9. To examine possible structural correlates of the thermodynamic and fine specificity signatures of the TCRs, the structure of unliganded QL9$\mathrm{L}^{\mathrm{d}}$ was solved and compared to structures of the $2 \mathrm{C}$ TCR/QL9- $\mathrm{L}^{\mathrm{d}}$ complex and three high-affinity TCR/QL9- $\mathrm{L}^{\mathrm{d}}$ complexes. Our findings show that the QL9- $\mathrm{L}^{\mathrm{d}}$ complex does not undergo major conformational changes upon binding. Thus, subtle changes in individual CDRs account for the diverse thermodynamic and kinetic binding mechanisms and for the different peptide fine specificities.
\end{abstract}

T cells recognize antigenic peptides bound to host major histocompatibility complex (MHC) 1 proteins via a surface receptor called the $\alpha \beta$ T cell receptor (TCR). The specificity of this

\footnotetext{
${ }^{\dagger}$ This work was supported by NIH Grants GM55767 (D.M.K.) and AI48540 (K.C.G.) and a predoctoral grant from the NSF (L.A.C.).

¥Atomic coordinates and experimental structure factor amplitudes of the QL9/L ${ }^{\mathrm{d}}$ complex have been deposited in the Protein Data Bank as entry 3ERY.

*Address correspondence to this author. Phone: 217-244-2821. Fax: 217-244-5858. E-mail: E-mail: d-kranz@uiuc.edu.

§University of Illinois.

\|Stanford University.

$\perp_{\text {Howard Hughes Medical Institute. }}$

SUPPORTING INFORMATION AVAILABLE

Several figures with legends that show the Scatchard plots of SPR binding data or the functional ability of various TCR transduced T cell lines. This material is available free of charge via the Internet at http://pubs.acs.org.

${ }^{1}$ Abbreviations: CDR, complementarity determining region; ITC, isothermal titration calorimetry; MHC, major histocompatibility complex; QL9, peptide with sequence QLSPFPFDL; QL9 Y5, peptide with sequence QLSPYPFDL; pMHC, peptide-MHC; scTCR, single-chain T cell receptor; RU, resonance units; SPR, surface plasmon resonance; TCR, T cell receptor.
} 
interaction is determined by the variable $(\mathrm{V})$ domains of the TCR, each of which contain three complementarity determining regions, or CDRs, that combine to form the TCR binding interface. General properties of TCR-peptide MHC (pMHC) interactions have been elucidated from crystal structures, showing that TCRs bind with a conserved diagonal docking orientation on the pMHC. This centers the highly variable CDR3 loops over the antigenic peptide, while germline-encoded CDR1s and CDR2s make contact with the MHC helices $(1,2)$. Although the orientation is conserved among different TCR-pMHC interactions, the relative contribution of each CDR to the binding energy varies among different TCR:pMHC systems $(3,4)$.

The ability of TCRs to cross-react with multiple pMHC ligands is an essential property that enables the immune system to recognize and eliminate many potential pathogens (5). This general property of TCRs has been attributed to conformational flexibility, in part due to structures of liganded and unliganded TCRs that show significant adjustments in the CDR loops, particularly the CDR3s, upon TCR-pMHC engagement (6-8). In support of a reduction of TCR mobility upon pMHC binding, low binding affinities, slow association kinetics, and unfavorable entropy changes have been reported (9-13). However, other studies have shown TCR-pMHC interactions with favorable entropy changes, sometimes in the presence of significant TCR conformational changes, indicating that other factors can overcome unfavorable entropy associated with decreased TCR flexibility (14-16). Although the peptide is generally assumed to be limited in movement, they have also been shown to undergo conformational adjustments upon TCR binding, indicating that movement of peptide residues should be taken into consideration in thermodynamic analysis of TCR-pMHC interactions $(17,18)$.

To further understand the structural correlates of TCR-pMHC thermodynamics, here we have studied a system that involves a single pMHC with a collection of structurally very related TCRs. The TCR was isolated from an alloreactive $T$ cell clone called $2 \mathrm{C}$ that recognizes $\mathrm{L}^{\mathrm{d}}$ as a foreign MHC (19) and a nonamer peptide from the ubiquitous enzyme $\alpha$-ketoglutarate dehydrogenase, called QL9 (QLSPFPFDL) $(20,21)$. The affinity of 2 C for QL9-L ${ }^{d}$ is in the low micromolar range (22). We previously engineered high-affinity mutants of the $2 \mathrm{C} \mathrm{TCR}$ against QL9- $\mathrm{L}^{\mathrm{d}}$ by randomizing five residues of the CDR3 $\alpha$ loop in a yeast surface display library $(23,24)$, and we have also isolated high-affinity mutants from similar libraries generated within the $\operatorname{CDR} 1 \beta, \operatorname{CDR} 2 \alpha$, and $\operatorname{CDR} 3 \beta$ loops (25). Our recent work on the structure of the $2 \mathrm{C} / \mathrm{QL} 9-\mathrm{L}^{\mathrm{d}}$ complex showed that this interaction has a high degree of shape complementarity and is entropically favorable. In contrast, high-affinity TCR mutant $3 \alpha-\mathrm{m} 6$, which differs by five residues in the CDR3 $\alpha$ and has a nearly identical structure, binds to the same ligand with unfavorable entropy (26).

To gain further insight into the nature of the binding interactions of individual CDR loops, we have examined this panel of high-affinity TCRs with mutations in different CDRs for thermodynamic and kinetic parameters of binding, as well as fine peptide specificity. In addition, we solved the structure of the unliganded QL9- $\mathrm{L}^{\mathrm{d}}$ complex to investigate whether significant conformational changes to the QL9 peptide could result in the observed thermodynamics or kinetics. We have recently solved the structure of the high-affinity TCR mutant $3 \alpha-\mathrm{m} 13$ in complex with QL9-L ${ }^{\mathrm{d}}$ (27) and used the existing structures of 2C/QL9- $\mathrm{L}^{\mathrm{d}}$ and the high-affinity $3 \alpha-\mathrm{m} 6 / \mathrm{QL} 9-\mathrm{L}^{\mathrm{d}}$ complexes (26) to further analyze the structural correlates of our thermodynamic, kinetic, and specificity data. Our results indicate that multiple thermodynamic and kinetic mechanisms exist for achieving high affinity and maintaining peptide specificity in this system. The disparate thermodynamics seen in the wild-type and high-affinity TCR-pMHC interactions are not due to large conformational adjustments of the peptide or the TCR but rather are due to modest conformational shifts in individual CDRs and/ or to subtle changes in only a few TCR residues at the interface. 


\section{EXPERIMENTAL PROCEDURES}

\section{Peptides and Antibodies}

$\mathrm{L}^{\mathrm{d}}$ binding peptides QL9 (QL-SPFPFDL), QL9 Y5 (QLSPYPFDL), and MCMV (YPHFMPTNL) were synthesized by standard F-moc chemistry at the Macromolecular Core Facility at Pennsylvaina State University College of Medicine (Hershey, PA) and purified by reversephase HPLC with a linear acetonitrile gradient. Hamster anti-mouse CD3 antibody 145-2C11 was purified from ascites fluid. Rat anti-mouse IL-2 antibody JES6-1A12, biotinylated rat antimouse IL-2 antibody JES6-5H4, and biotinylated hamster anti-mouse TCR C $\beta$ antibody H57-597 were all obtained from BD Pharmingen.

\section{Protein Expression and Purification}

A mutant of $2 \mathrm{C}$, called $\mathrm{T} 7$, contains six stability mutations ( $447 \mathrm{Y} \beta, \mathrm{L} 81 \mathrm{~S} \beta, \mathrm{G} 17 \mathrm{E} \beta$, L43P $\alpha$, $\mathrm{W} 82 \mathrm{R} \alpha$, and $\mathrm{I} 118 \mathrm{~N} \alpha)(28)$ and was used for soluble protein expression, and all high-affinity mutants also contained the T7 stability mutations. An additional mutation to the $\mathrm{V} \beta$ domain that has been shown to increase protein solubility was also added (I78T $\beta)$ (29). Single chain TCRs (scTCRs) were cloned into pET22b (Novagen) as an NcoI/XhoI fragment in the V $\alpha$ $\left(\mathrm{Gly}_{4}{ }_{4} \mathrm{Ser}\right)_{4}$ linker-V $\beta$ orientation with a C-terminal 6-histidine tag and an $\mathrm{N}$-terminal Pel B leader peptide for periplasmic expression. Protein was expressed in BL21(DE3) Codon Plus Escherichia coli (Stratagene) as previously described and further purified by Ni-affinity and gel filtration chromatography (Superdex S-200 10/300 column, Amersham Biosciences) (30).

A platform $\mathrm{L}^{\mathrm{d}}$ module containing only the $\alpha 1$ and $\alpha 2$ domains and five stability mutations (N30D, A49V, I66V, W97R, and K131R), called $\mathrm{L}^{\mathrm{d}}-\mathrm{m} 31$, was expressed as inclusion bodies, refolded in the presence of $\mathrm{L}^{\mathrm{d}}$-binding peptides, and purified by gel filtration chromatography as described (30). A C-terminal biotinylation tag was added to $\mathrm{L}^{\mathrm{d}}-\mathrm{m} 31$ to facilitate immobilization in SPR experiments. For crystallization, three additional mutations were added to $\mathrm{L}^{\mathrm{d}}$-m31 (F9Y, V12T, and I23T) to increase solubility (26).

\section{Isothermal Titration Calorimetry}

Protein expression and purification were performed as described, except that TCR samples were treated overnight with carboxypeptidase $\mathrm{A}$ and $\mathrm{B}$ at $4{ }^{\circ} \mathrm{C}$ prior to size exclusion chromatography, and the MHC was expressed without the C-terminal biotinylation tag. All proteins were purified in the same buffer $(10 \mathrm{mM}$ HEPES, $150 \mathrm{mM} \mathrm{NaCl}, \mathrm{pH}$ 7.2) to minimize heat of dilution effects. Thermodynamic parameters were determined using a VP-ITC calorimeter (MicroCal, Northhampton, MA) at $20{ }^{\circ} \mathrm{C}$. Protein samples were degassed prior to titrations. Titrations were performed with a range of concentrations. Conditions giving the strongest signal with the lowest background were QL9-L ${ }^{\mathrm{d}}(185 \mu \mathrm{M})$ injected into $2 \mathrm{C}(45 \mu \mathrm{M})$ and QL9-L $\mathrm{L}^{\mathrm{d}}(52 \mu \mathrm{M})$ injected into $3 \alpha-\mathrm{m} 6(5 \mu \mathrm{M})(26)$. Further calorimetry was performed for QL9-L ${ }^{\mathrm{d}}(53 \mu)$ injected into $1 \beta-\mathrm{m} 3(10.5 \mu \mathrm{M})$, QL9- $\mathrm{L}^{\mathrm{d}}(46.5 \mu \mathrm{M})$ injected into $3 \alpha-\mathrm{m} 13$ (5 $\mu \mathrm{M})$, and QL9- $\mathrm{L}^{\mathrm{d}}(46.5 \mu)$ injected into $3 \beta-\mathrm{m} 4(5 \mu \mathrm{M})$. Experiments at other concentrations yielded similar thermodynamic parameters (data not shown). Injection volumes were adjusted to yield an initial signal of $-0.1 \mathrm{kcal} / \mathrm{mol}$ of injectant, as determined experimentally for each TCR. MHC was injected into TCR for all ITC experiments. While injection of either compound yielded similar results, one TCR $(1 \beta$-m 3$)$ was unstable at high concentrations. As the cell concentration is 7-8-fold lower than the syringe concentration, TCR was placed in the cell for all experiments, in order to avoid precipitation of $1 \beta$-m3 TCR. Data were processed using MicroCal Origin 5.0 software, and thermodynamic parameters were calculated using the equation 
where $R$ is the universal gas constant $\left(1.9872 \mathrm{cal} \mathrm{mol}^{-1} \mathrm{~K}^{-1}\right), T$ is the temperature in kelvin, $K$ is the association constant, $\Delta G$ is the change in Gibbs free energy, $\Delta H$ is the change in enthalpy, and $\Delta S$ is the change in entropy.

\section{Surface Plasmon Resonance}

Affinity and kinetic parameters associated with scTCR/peptide- $\mathrm{L}^{\mathrm{d}}$ binding were measured on a BIAcore 3000 instrument. Streptavidin sensor chips (BIAcore) were conditioned with three consecutive $1 \mathrm{~min}$ injections of $1 \mathrm{M} \mathrm{NaCl}$ and $50 \mathrm{mM} \mathrm{NaOH}$. Biotinylated peptide- $\mathrm{L}^{\mathrm{d}}-\mathrm{m} 31$ was immobilized to a level of 450-500 response units (RU), and the remaining surface was blocked with a 5 min injection of $1 \mu \mathrm{M}$ biotin. ScTCRs were injected at a flow rate of $30 \mu \mathrm{L} /$ min at varying concentrations, depending on the affinity of the interaction. Peptide was added to all scTCR samples at $1 \mu \mathrm{M}$ to extend the lifetime of the immobilized pMHC surface, and binding to a blank biotin-blocked control surface was subtracted from all measurements. Kinetic data were analyzed using simultaneous $k_{\mathrm{a}} / k_{\mathrm{d}}$ determination with a 1:1 Langmuir binding model on BIAevaluation 3.0 software (BIAcore). Equilibrium affinities were determined by linear regression of RU at equilibrium versus RU/scTCR concentration (30).

\section{Transfection of $58^{-/-} \mathrm{T}$ Cells}

We have previously described the production of $2 \mathrm{C}$ and $3 \alpha-\mathrm{m} 6 \mathrm{~T}$ cell transfectants using the SFFV expression plasmid and T cell hybridoma line $58^{-/-}(31)$, and transfectants expressing the $3 \alpha-\mathrm{m} 13$ TCR were generated at the same time. The remaining mutants $(2 \alpha-\mathrm{m} 1,3 \beta-\mathrm{m} 4$, and $1 \beta$-m3) were retrovirally transfected into $58^{-/-}$cells using the murine stem cell virus (MSCV) vector. To ensure that both systems were similar in expression level and functional responses, a retroviral transfectant of the $2 \mathrm{C}$ receptor was also generated. The $\alpha$ and $\beta$ chains of the $2 \mathrm{C}$ TCR and high-affinity $2 \mathrm{C}$ mutants were cloned into the MSCV retroviral vector, and DNA was prepared using the Qiagen Maxi-prep kit. Viral packaging cell line 293T was transfected using the CalPhos mammalian transfection kit (Clontech). At $48 \mathrm{~h}$ posttransfection, viral supernatant was collected, $8 \mu \mathrm{g} / \mathrm{mL}$ Polybrene 8 was added, and the mixture was filter sterilized. T cell hybridoma lines $58^{-/-}$or $58^{-/-} \mathrm{CD} 8 \alpha \beta$ were diluted to a density of $5 \times 10^{6}$ cells $/ \mathrm{mL}$, and $100 \mu \mathrm{L}$ of cells and $1 \mathrm{~mL}$ of viral supernatant mixture were placed in one well of a 24-well plate. Cells were spin-infected for $45 \mathrm{~min}$ at $1200 \mathrm{~g}$ at room temperature, washed, transferred to flasks, and grown at $37^{\circ} \mathrm{C}, 5 \% \mathrm{CO}_{2}$ in supplemented RPMI medium. Cells were assayed for transgene expression after 3 days, and infection efficiency of $\sim 20 \%$ was common.

Because the vector used has no markers for selection, transfectant lines were stained with a biotinylated anti-TCR C $\beta$ antibody and streptavidin-conjugated phycoerythrin (SA: PE), and cells expressing the transgene were isolated using fluorescence activated cell sorting (FACS) and expanded. Surface levels of TCR, CD8 $\alpha$, and CD $8 \beta$ were compared across all mutants from both transfection methods using flow cytometry. Levels of TCR and CD8 $\beta$ were consistent between the two methods of transfection, but CD8 $\alpha$ levels were significantly lower in retroviral transfectants (data not shown). To control for this difference, $2 \mathrm{C}$ transfectants generated from both methods were included in functional assays and exhibited similar $\mathrm{SD}_{50}$ values upon stimulation with peptide.

\section{T Cell Activation Assays}

$2 \mathrm{C}$ and high-affinity transfectants were examined for IL-2 release in response to various amounts of QL9 or QL9-Y5 peptides added to $\mathrm{L}^{\mathrm{d}}$-bearing cells, T2- $\mathrm{L}^{\mathrm{d}}$. In addition, transfectants were stimulated with an immobilized anti-CD3 antibody for maximal IL-2 release 
and null peptide MCMV. Transfectants, T2- $\mathrm{L}^{\mathrm{d}}$ cells, and peptides were incubated together for $24 \mathrm{~h}$, and supernatants were assayed for IL-2 with an ELISA as described (31). Results are plotted as percent maximal IL-2 release $=\left[\left(A_{450}\right.\right.$ sample $-A_{450}$ null $) /\left(A_{450} \mathrm{CD} 3-A_{450}\right.$ null $\left.)\right]$ $\times 100$, where $A_{450}$ is the absorbance at $450 \mathrm{~nm}$ of a transfectant stimulated with the indicated peptide concentration ( $A_{450}$ sample), MCMV $\left(A_{450}\right.$ null), or an anti-CD3 antibody ( $\left.A_{450} \mathrm{CD} 3\right)$.

\section{QL9-Ld Crystallization, Data Collection, and Processing}

Purified QL9-L ${ }^{\mathrm{d}}-\mathrm{m} 31$ in $10 \mathrm{mM}$ HEPES and $50 \mathrm{mM} \mathrm{NaCl}, \mathrm{pH}$ 7.0, was concentrated to 12.5 $\mathrm{mg} / \mathrm{mL}$. Crystals were obtained in $0.4 \mathrm{M}$ ammonium phosphate monobasic (condition no. 3 in Hampton Research Crystal Screen) using the hanging drop method at room temperature. Crystals were cryoprotected with 30\% glycerol, and data were collected on beamline X29A at the National Synchrotron Light Source at Brookhaven National Laboratory (BNL, Upton, NY). Crystals diffracted to $1.95 \AA$, cell dimensions $a=47.2 \AA, b=74.3 \AA, c=53.3 \AA$, in space group $P 2{ }_{1}$. Data were indexed, integrated, and scaled using the program HKL2000 (32).

\section{QL9-Ld Structure Solution and Refinement}

The initial phasing was obtained by the molecular replacement method with the program Phenix (33) using the structural component of $\mathrm{L}^{\mathrm{d}}$ in the structure of the $2 \mathrm{C} / \mathrm{QL} 9-\mathrm{L}^{\mathrm{d}}$ ternary complex as the search model. The initial model of $\mathrm{L}^{\mathrm{d}}$ was built using the programs $\mathrm{O}$ and Coot $(34,35)$. After several rounds of refinement of the structure of $\mathrm{L}^{\mathrm{d}}$ using the program CNS (36), QL9 was added to the model based on the improved election density for the peptide. The QL9-L ${ }^{\mathrm{d}}$ binary complex was further refined using program CNS. The final model has $R_{\text {work }}$ of $23.2 \%$ and $R_{\text {free }}$ of $28.3 \%$, respectively.

\section{RESULTS}

\section{Thermodynamics of High-Affinity TCR/QL9-Ld Interactions}

For biophysical analysis of $2 \mathrm{C}$ high-affinity mutants, a panel of six TCRs (wild-type $2 \mathrm{C}$ and five higher affinity mutants: $3 \beta-\mathrm{m} 4,2 \alpha-\mathrm{m} 1,1 \beta-\mathrm{m} 3,3 \alpha-\mathrm{m} 13$, and $3 \alpha-\mathrm{m} 6)$ were cloned into an E. coli expression vector as stabilized single-chain constructs, expressed, and purified (Figure 1). Each mutant contained from two to five mutations, but it is notable that in each case the mutations include at least one charged residue that changes the overall electrostatic potential of the CDR. Accordingly, increases in affinity and any associated changes in thermodynamic binding mechanisms could be due to the differences in chemistries of these mutated side chains compared to the wild-type residues.

To examine the effect of high-affinity mutations in various regions of the $2 \mathrm{C}$ TCR on the thermodynamics of QL9-L ${ }^{\mathrm{d}}$ binding, we performed isothermal titration calorimetry (ITC) on all high-affinity mutants with QL9- $\mathrm{L}^{\mathrm{d}}$, using a stabilized $\alpha 1 / \alpha 2$ module called $\mathrm{L}^{\mathrm{d}}-\mathrm{m} 31$ (30) (Figure 2, Table 1). In contrast to the $2 \mathrm{C}$ TCR, most mutants bind QL9- $\mathrm{L}^{\mathrm{d}}$ with unfavorable entropy and exhibit favorable enthalpy changes compared to $2 \mathrm{C}$. It is particularly notable that $3 \beta$ - $\mathrm{m} 4$ contains only two mutations, but there was a very different thermodynamic signature for QL9- $\mathrm{L}^{\mathrm{d}}$ binding compared to $2 \mathrm{C}$ binding. In contrast, $1 \beta$-m3, which also contains only two mutations, retained the same thermodynamic binding mechanism seen in the $2 \mathrm{C}$ receptor. Thus multiple thermodynamic mechanisms account for binding by high-affinity $2 \mathrm{C}$ TCR mutants to QL9-L ${ }^{\mathrm{d}}$.

\section{Binding Affinity and Kinetics of High-Affinity TCR/QL9-Ld ${ }^{d}$ Interactions}

We previously examined the relative affinities and fine peptide specificities of several highaffinity TCRs on the surface of yeast cells by labeling them with QL9-L ${ }^{\mathrm{d}}$-Ig dimers and analyzing them using flow cytometry (25). This approach is only qualitative due in part to the 
bivalency of the QL9-L ${ }^{\mathrm{d}}$ ligand. To obtain more information regarding the binding properties of these interactions, we used surface plasmon resonance (SPR) with immobilized biotinylated QL9-L ${ }^{d}-m 31$ monomers to determine equilibrium binding affinities and kinetic parameters associated with high-affinity TCR-pMHC interactions (Figure 3 and Table 1). Equilibrium binding constants were calculated from ITC, equilibrium measurements using SPR, and kinetic parameters using SPR, and all of the TCRs showed the same relative order of affinity.

The $2 \alpha-\mathrm{m} 1$ and $3 \beta$-m 4 mutants had affinity increases compared to $2 \mathrm{C}$ of approximately 6 -fold. Although their affinity for QL9- $\mathrm{L}^{\mathrm{d}}$ was similar, $2 \alpha-\mathrm{m} 1$ and $3 \beta-\mathrm{m} 4$ used different kinetic strategies to achieve enhanced equilibrium binding. The increase in affinity of $2 \alpha-\mathrm{m} 1$ was due entirely to a decreased off-rate, while $3 \beta$-m 4 exhibited a combination of increased association rate and decreased dissociation rate. The other mutants, $3 \alpha-\mathrm{m} 13,1 \beta$-m3, and $3 \alpha-\mathrm{m} 6$, had more substantial affinity increases of 23-, 28-, and 242-fold, respectively. Again, these mutants varied in the contribution of association and dissociation rates to the overall affinity, with $1 \beta$ $\mathrm{m} 3$ having a nearly 10-fold increase in association rate, the largest increase of all TCRs measured here. In contrast, the $3 \alpha-\mathrm{m} 6$ mutant exhibited the largest change in dissociation rate, almost 100-fold slower than the wt 2C TCR. Thus, multiple kinetic mechanisms were used to achieve higher affinity binding in the interactions of diverse TCRs with the same pMHC ligand.

\section{Fine Peptide Specificity of High-Affinity TCRs}

Different regions of the TCR have been proposed to have different effects on peptide specificity of TCR-pMHC interactions, and our panel of TCR mutants offers an opportunity to better understand the effects of each CDR on the fine peptide specificity of $2 \mathrm{C}$. We have previously described a QL9 peptide variant, called QL9-Y5, that contains a phenylalanine to tyrosine substitution at position 5 . The side chain at this position has been shown to influence binding to both the TCR and the $\mathrm{L}^{\mathrm{d}}$, yet the 2C TCR recognizes QL9-Y5 and QL9 similarly (37). To compare the fine specificity of high-affinity TCR mutants, we measured equilibrium affinity and kinetic parameters associated with binding to QL9-Y5-L ${ }^{\mathrm{d}}$ using SPR (Figure 3 and Table 1). The ratio of affinity values of each TCR mutant for QL9- $L^{d}$ and QL9-Y5- $L^{d}$ was plotted to more clearly represent the changes in fine peptide specificity (Figure 4).

The 2C TCR binds to QL9-Y5- $\mathrm{L}^{\mathrm{d}}$ with an affinity of $2.6 \mu \mathrm{M}$, in agreement with reports showing that binding of 2 C TCR to QL9-Y5- $\mathrm{L}^{\mathrm{d}}$ and QL9- $\mathrm{L}^{\mathrm{d}}$ expressed on target cells is similar (37). All high-affinity TCR mutants maintained higher affinity binding than the wt $2 \mathrm{C}$ TCR to the F5Y variant (Figure 3, right, and Table 1). This is not unexpected, as the difference between the two peptides is a single hydroxyl group. However, there was a significant quantitative difference among the TCR mutants in their binding to QL9 versus the F5Y variant. The $2 \alpha-$ $\mathrm{m} 1$ and $3 \beta$ - $\mathrm{m} 4$ mutants were most similar to $2 \mathrm{C}$ in terms of the ratio of binding to QL9 versus QL9-Y5. Although the affinity for both ligands was increased, $2 \alpha-\mathrm{m} 1$ and $3 \beta-\mathrm{m} 4$ maintained a similar level of specificity (Figure 4 ). The maintenance of fine peptide specificity by the $2 \alpha-\mathrm{m} 1$ mutant is consistent with our previous yeast display studies and with studies of a highaffinity variant of the human $1 \mathrm{G} 4 \mathrm{TCR}$, that was isolated from CDR2 phage display libraries and also maintained a high degree of fine specificity (38). In contrast to the CDR3 $\beta$ mutant $3 \beta$ - 44 , both affinity mutants in CDR3 $\alpha$ had $8-10$-fold improvements in binding to the Y5 variant relative to QL9 (Figure 4). The slower dissociation rate for each CDR3 $\alpha$ mutant bound to QL9-Y5-L ${ }^{\mathrm{d}}$, compared to QL9- $\mathrm{L}^{\mathrm{d}}$, suggests that the hydroxyl group interacts favorably with the mutants and generates a more stable complex.

In direct contrast to the CDR3 $\alpha$ mutants, mutant $1 \beta$ - $\mathrm{m} 3$ had an 8 -fold reduction in affinity for QL9-Y5-L ${ }^{d}$ relative to QL9- ${ }^{d}$. Thus, while other high-affinity mutants bind to QL9-Y5 with similar or higher affinity relative to QL9- $\mathrm{L}^{\mathrm{d}}$, the $1 \beta$ - $\mathrm{m} 3$ mutant exhibited enhanced fine peptide specificity and a stronger preference for the QL9 peptide. The net difference in binding to the two alternative peptides between the structurally similar TCRs $3 \alpha-\mathrm{m} 6$ and $1 \beta$-m 3 was $\sim 60$-fold 
(8-fold increase of QL9-Y5 > QL9 and 8-fold reduction QL9-Y5 < QL9, respectively), indicating that it is possible to manipulate different CDRs to generate quite significant differences in peptide specificity. This feature should allow the engineering of TCRs with desirable cross-reactivities (e.g., with improved reactivities for common viral escape mutations).

\section{Functional Studies of High-Affinity TCR Transfectants}

Binding and thermodynamic studies on this collection of TCRs provided an opportunity to assess the biological impact of these properties and to evaluate the reactivity with the two peptides (QL9 and QL9-Y5). To understand the effect of measured thermodynamic and kinetic parameters on T cell activation, we generated T cell transfectants of each mutant in the $\alpha \beta$ negative $\mathrm{T}$ cell hybridoma $58^{-1-}$ and monitored their responses to $\mathrm{L}^{\mathrm{d}}$-bearing cells exogenously loaded with QL9 and QL9-Y5 peptides (Figure 5). The response of 2C to QL9- ${ }^{\mathrm{d}}$ is CD8 independent (39), and accordingly, $58^{-/-} \mathrm{T}$ cell transfectants lacking CD8 have been shown to secrete IL-2 in the presence of QL9 peptide and $\mathrm{L}^{\mathrm{d}}$-bearing antigen presenting cells (31). ${ }^{2}$ Consistent with this result, $2 \mathrm{C}$ transfectants exhibited CD8-independent activation in response to QL9- $\mathrm{L}^{\mathrm{d}}$, and all of the higher affinity mutants maintained CD8-independent activation in response to QL9-L ${ }^{\mathrm{d}}$ (Figure 5A). This result suggests that as long as the equilibrium binding affinity (or $t_{1 / 2}$ ) of the TCR-pMHC interaction is above a threshold, the specific thermodynamic mechanisms involved in binding may not be critical for CD8-independent activation. As expected, all of these TCRs also showed optimal activity in the presence of CD8 (Supporting Information Figure 2). These results lend further support to the view that there is not an optimal dwell time $\left(t_{1 / 2}\right)$ for the TCR-pMHC interaction. This still controversial hypothesis proposes that there would be a loss of activity for TCRs with longer half-lives (43), yet among this collection of TCRs, all of them mediated strong agonist activity with subnano-molar $\mathrm{SD}_{50}$ values (sensitization doses at 50\% maximum) in the presence or absence of CD8 (Supporting Information Figure 3).

Activation of high-affinity transfectants in response to the QL9-Y5 peptide variant was also examined (Figure 5B), and CD8-independent activation was maintained in all mutants. There was little if any improvement in the $\mathrm{SD}_{50}$ of high-affinity $\mathrm{T}$ cell transfectants in response to either peptide, relative to $2 \mathrm{C}$. Thus the affinity of the wild-type receptor for QL9-L ${ }^{\mathrm{d}}$ and QL9Y5- $\mathrm{L}^{\mathrm{d}}$ is sufficiently high (i.e., above the threshold), and the increased affinity of the mutants had little effect on the functional $\mathrm{T}$ cell response. In addition, there was no clear correlation between the kinetic or thermodynamic strategy used to achieve high affinity for QL9-L ${ }^{\mathrm{d}}$ or QL9-Y5- $\mathrm{L}^{\mathrm{d}}$ and the level of $\mathrm{T}$ cell activation. Studies with $2 \mathrm{C}$ and the $\mathrm{K}^{\mathrm{b}}$ peptide ligands, p2Ca, dEV8, and SIY, have shown that there is a direct correlation between T cell activity and stability of the peptide- $\mathrm{K}^{\mathrm{b}}$ complex $(44,45)$. Large negative heat capacities, consistent with conformational reorganization of the $2 \mathrm{C}$ TCR-pep- $\mathrm{K}^{\mathrm{b}}$ complexes, were observed for each of these TCR-pep- $\mathrm{K}^{\mathrm{b}}$ interactions, but in these instances peptide binding to $\mathrm{K}^{\mathrm{b}}$ appeared to be the more decisive factor in determining peptide potency (45). Accordingly, it is possible that thermodynamics, kinetics, or heat capacity (as a measure of conformational reorganization) only influence activity when the binding affinities of the interaction are near the activity threshold, not well above the threshold as is likely the case for the TCR mutants analyzed here.

\footnotetext{
${ }^{2}$ Our definition for CD8 dependence is whether the T cell requires CD8 for the observed T cell activity. Accordingly, CD8 independence referred to here is evaluated by examining the activity mediated by $\mathrm{T}$ cells that do not express CD8. It should be pointed out that many studies, including those with the QL9-related ligand p2Ca (40), have attempted to assess the requirement for CD8 by using anti-CD8 antibodies. In this case, the ability to block T cell activity with the anti-CD8 antibodies led to the conclusion that the TCR acted in a CD8-dependent manner. However, these studies are complicated by virtue of the fact that inhibition with anti-CD8 antibodies can be influenced by the level of the ligand and by the epitope that is recognized. Some anti-CD8 antibodies thus appear to act by interfering with CD8/TCR associations and subsequent signaling (41), while others act by direct inhibition of the CD8/class I interaction (42).
} 
Alternatively, the thermodynamic mechanisms that are involved do not influence $\mathrm{T}$ cell activity at any affinity, and only the equilibrium binding and/or dissociation kinetics are important.

\section{Unliganded QL9-Ld Structure}

To determine if the QL9 peptide undergoes conformational adjustments upon TCR binding that contribute to the kinetic and thermodynamic parameters observed here, we solved the crystal structure of the unliganded QL9-L ${ }^{\mathrm{d}}$-m31 complex at a resolution of $1.95 \AA$. The unit cell contained two molecules: form A, in which the structure of QL9 is similar to that of the 2C/QL9- L $^{\mathrm{d}}$ complex, and form B, in which the structure of QL9 is altered, compared to the 2C/QL9-L ${ }^{d}$ complex. Form B contained large areas of the MHC molecule (residues 41-61 and 171-175) and the leucine at position 2 of QL9 that did not contain adequate electron density to determine the structure. Moreover, the peptide region of form $\mathrm{B}$ had multiple contacts with the $\alpha 2$ helix of form A. In contrast, form A had good electron density throughout (Figure 6A), and the peptide region contained considerably fewer contacts with the form B molecule. For these reasons, our analysis of the structure will focus on form A.

The structures of the $\mathrm{L}^{\mathrm{d}} \mathrm{MHC}$ in bound and unbound forms are virtually identical, with an rmsd value of 0.619. An overlay of the QL9 peptide from TCR bound and unbound structures is shown in Figure 6B. The peptide backbone and side chain conformations are remarkably similar, with the exception of the phenylalanine at position 5 . We have previously shown that the central aromatic residues of the QL9 peptide hinge to form a planar, "propeller-like" surface when $2 \mathrm{C}$ is engaged (26), and we suggested that the TCR may push these residues into this conformation upon binding, similar to that observed in the ESL4/EPLP-HLA-B35 complex (17). However, in the unliganded structure of QL9- $\mathrm{L}^{\mathrm{d}}$, the prolines at positions 4 and 6 and the phenylalanine at position 7 all remain in the same planar conformation, indicating the TCR does not alter the conformation of these residues upon binding. The side chain of the central phenylalanine residue at position 5 lacked any discernible electron density (it was changed to an alanine in the structure to reflect this). It is likely that this residue is mobile in the unliganded QL9- ${ }^{\mathrm{d}}$ complex and becomes ordered upon TCR binding. Thus, with the exception of the central phenylalanine residue, the QL9 peptide backbone and side chains do not undergo major conformational adjustments upon TCR engagement. Accordingly, we suggest that the differences in thermodynamics of binding among the TCRs could be due to subtle conformational changes in CDRs and/or the chemical differences in the mutated CDR residues at the interface, rather than to conformational plasticity of the peptide or $\mathrm{L}^{\mathrm{d}}$.

\section{TCR/QL9-Ld Complex Structures}

We have previously described the structures of the 2C/QL9-L ${ }^{\mathrm{d}}$ (PDB ID 2OI9) and m6/QL9$\mathrm{L}^{\mathrm{d}}$ (PDB ID 2E7L) complexes (26), and we have recently solved the structure of the highaffinity TCR mutant, $3 \alpha-\mathrm{m} 13$, in complex with QL9-L ${ }^{\mathrm{d}}$ (2.95 ̊̊ resolution, PDB ID 3E3Q) (27). To further explore the possible structural correlates of binding thermodynamics, kinetics, and specificity of the TCRs, we compared all three TCR/QL9-L ${ }^{\mathrm{d}}$ complex structures. The three complexes are virtually identical in the docking footprint of each TCR on the pMHC and in the conformation of individual CDR loops, with the exception of the CDR $3 \alpha$, which contained mutations in $3 \alpha-\mathrm{m} 6$ and $3 \alpha-\mathrm{m} 13$ (rmsd $=0.378$ for $\mathrm{m} 6$ and 1.056 for $\mathrm{m} 13$ ) (Figure 7A, B). In the $2 \mathrm{C}$ complex, CDR $3 \alpha$ is pointed over the helix and away from the peptide. In the $\mathrm{m} 6$ and m13 complexes, CDR3 $\alpha$ flips back over the QL9 peptide, allowing increased contacts with QL9 and more extensive inter- and intraloop stabilizing interactions. These mutants bind to QL9- $\mathrm{L}^{\mathrm{d}}$ with highly favorable enthalpy changes, relative to $2 \mathrm{C}$, suggesting that these contacts with the pMHC contribute to the stabilization of the complex and to the higher affinity.

Contrary to our expectations, both CDR $3 \alpha$ mutants bound to QL9-L ${ }^{\mathrm{d}}$ with unfavorable entropy, despite the fact that structural and kinetic data were consistent with more rigid CDRs than the 
wild-type 2C TCR. This finding may imply that other factors negate the potential positive effect that reduced loop flexibility has on binding entropy. For example, both CDR3 $\alpha$ mutants contain additional charged residues (two potential positive charges from $\mathrm{m} 6$ and a negative charge for m13), and either electrostatic or hydrophobic effects could be important in the differences with the 2C TCR. Regardless of the mechanism that accounts for the thermodynamic signature of each high-affinity TCR-pMHC interaction, it is clear from the overall similarity of the structures that subtle changes to the structure of a single CDR loop can quite significantly affect the thermodynamics of the interaction.

We asked whether the structures of the high-affinity CDR3 $\alpha$ mutants might reveal a mechanism that accounts for the higher affinity that $3 \alpha-\mathrm{m} 6$ and $3 \alpha-\mathrm{m} 13$ had for the QL9-Y5 peptide variant, compared to QL9. Substitution of a tyrosine residue into QL9 of the TCR/QL9-L ${ }^{\mathrm{d}}$ structures suggested that the CDR3 $\alpha$ backbone and side chains would be too far away to make contact with the additional hydroxyl group (Figure 7C). To facilitate a direct interaction between CDR3 $\alpha$ and the QL9-Y5 hydroxyl group, either the CDR3 $\alpha$ or the tyrosine side chain must adopt a different conformation. A tyrosine conformational change might be the most likely explanation given the apparent mobility of the phenylalanine in the unliganded QL9- $\mathrm{L}^{\mathrm{d}}$ structure. Alternatively, the increased affinity of these mutants for QL9-Y5-L ${ }^{\mathrm{d}}$ may be indirect and mediated through other CDRs. However, it has been noted that the other CDRs in the 2C system exhibit minimal changes in either the mutant complexes (27) or when 2C TCR is bound to its collection of $\mathrm{K}^{\mathrm{b}}$ ligands (46).

Finally, we examined whether it is possible to suggest a mechanism that underlies the reduced affinity of the $1 \beta-\mathrm{m} 3$ mutant for QL9-Y5- $\mathrm{L}^{\mathrm{d}}$, compared to QL9- ${ }^{\mathrm{d}}$. In the $2 \mathrm{C}$ TCR, residues $\mathrm{N} 28$ and N31 (that are mutated to Gly28 and Arg31 in $1 \beta$-m3) flank the aspartic acid at position 8 of QL9 (Figure 7D). The arginine at residue 31 of $1 \beta$-m3 would be within a distance that could form electrostatic interactions with Asp8 of QL9. Electrostatic steering could account for the enhanced association rate of this interaction and may also be related to the favorable entropy change described above. It is possible that the tyrosine of the QL9-Y5 peptide could influence this interaction. Obviously, structures of the $1 \beta$-m3 mutant in complex with QL9$\mathrm{L}^{\mathrm{d}}$ and QL9-Y5- $\mathrm{L}^{\mathrm{d}}$ will be necessary to examine these possibilities.

\section{DISCUSSION}

During the lifetime of a T cell, the $\alpha \beta$ T cell receptor must recognize multiple different pMHC ligands in order for the cell to function. For example, the TCR recognizes a self-peptide bound to an $\mathrm{MHC}$ protein during selection in the thymus, thereby promoting $\mathrm{T}$ cell differentiation and migration to the peripheral lymphoid system. Subsequently, the TCR is capable of binding to a foreign antigenic peptide, most often associated with the same MHC protein, thereby driving the $\mathrm{T}$ cell to activation and elimination of the foreign agent. Finally, TCRs can bind to a foreign MHC protein (such as $\mathrm{L}^{\mathrm{d}}$ in the $2 \mathrm{C}$ system) in situations that involve tissue transplants, thereby leading to transplant rejection (allore-actions).

To accomplish the recognition of different pMHC complexes, it has been proposed that TCRs exhibit flexibility in their CDRs, facilitating an "induced fit" mechanism of ligand binding (reviewed by Armstrong et al. (46)). Recent studies, however, have suggested that structurally diverse TCRs can exhibit different thermodynamic binding mechanisms $(13,15,47)$. In the present report we have extended this observation to show that even a collection of structurally very similar TCRs, with as few as two amino acid substitutions, can exhibit diverse thermodynamic signatures for binding to the same pMHC ligand. By examining the reactions with the same pMHC ligand, we have avoided the possible influence of differences in the dynamics of the pMHC ligand that might account for the diverse TCR-pMHC binding thermodynamics. 
In addition to examining the collection of TCRs against the same pMHC ligand, the structure of the unliganded pMHC (QL9- $\mathrm{L}^{\mathrm{d}}$ ) was solved in order to assess whether the peptide undergoes significant structural changes upon TCR binding. Our results show that although there are minor adjustments of the peptide backbone and several side chains, there is no evidence of major structural reorganization. The side chain that appears to have the most mobility, as judged by a lack of electron density, was the phenylalanine at position 5 of QL9. We have shown previously that substitutions at this position can influence either $\mathrm{L}^{\mathrm{d}}$ binding or TCR binding, consistent with the possibility that side chain mobility and its position could vary depending on the nature of the side chain (37). However, given the similar location of Phe5 in the $2 \mathrm{C} /$ QL9-L ${ }^{\mathrm{d}}, \mathrm{m} 6 / \mathrm{QL}^{-} \mathrm{L}^{\mathrm{d}}$, and $\mathrm{m} 13 / \mathrm{QL} 9-\mathrm{L}^{\mathrm{d}}$ complexes, we suggest that even this position may not contribute appreciably to the differences in thermodynamics of binding by the TCRs.

Nevertheless, it is clear from studies of different TCRs binding to the same pMHC that the side chain of a peptide residue can have quite divergent impacts on their binding energies (48). Here, we show that the divergent impact can even extend to a collection of TCRs that are structurally very similar.

The $1 \beta$-m 3 mutant was unique among the TCRs in that it exhibited favorable entropy (like wt 2C), an affinity increase associated largely with a faster on-rate, and enhanced specificity for the phenylalanine at QL9 position 5, relative to a tyrosine at this position. We have speculated that these effects may be related to an Arg31-Asp8 electrostatic interaction between the $1 \beta$ $\mathrm{m} 3 \mathrm{TCR}$ and QL9 peptide, respectively. In this scenario, the electrostatic interaction could lead to both a faster on-rate and reduced entropic penalty associated with binding. The hydroxyl of the tyrosine at position 5 could be in sufficient proximity to influence this interaction. Alternatively, the thermodynamic binding signatures of these TCR mutants could be influenced, or even dominated, by a hydrophobic effect as has been observed in an elegant study of the role of a single tryptophan residue at the interface of the HEL antibody-lysozyme complex (49). A recent comparative analysis of the structures of nine pairs of liganded and unliganded TCRs has shown that there is a hierarchy of conformational changes in different CDRs: $3 \alpha>3 \beta>1 \alpha>2 \alpha>2 \beta>1 \beta$ (46). Furthermore, their analysis suggested that conformational changes in CDRs in systems such as $2 \mathrm{C}$ are also associated with other changes at the interface, including electrostatic potential within the buried surface area of the TCR. Thus, it is especially difficult to attribute differences in thermodynamic signatures to any single mechanism, such as conformational effects, rather than to other differences at the interface (e.g., as indicated above, each of the mutants described here has at least one mutated residue that is charged). Additional studies of the dynamics of these interactions, using NMR or perhaps fluorescence-based approaches, will be required to more fully understand the mechanisms involved.

Finally, it is worth noting that CDR1, which is thought to have a less important role in peptide specificity than the CDR3s, actually exhibits the highest degree of specificity when comparing QL9 to the tyrosine 5 variant. This finding provides additional support to the notion that each of the CDRs is positioned to provide, directly or indirectly, a degree of peptide specificity that is the hallmark of $\mathrm{T}$ cell immunity.

Regardless of the mechanisms involved in discriminating structurally similar peptides, our results show that it is possible to engineer enhanced specificity into the interaction with peptide, as might be desirable in reactions with tumor antigens in order to avoid reactivity with a structurally similar self-antigen. Alternatively, we have shown with the high-affinity mutants $3 \alpha-\mathrm{m} 6$ and $3 \alpha-\mathrm{m} 13$ that one could engineer enhanced affinity against a peptide variant, as might be desirable for known viral escape variants that contain defined amino acid substitutions in key T cell epitopes. 
In summary, this study shows that subtle changes in the structure of a single CDR can have profound effects on the thermodynamics and kinetics of TCR-pMHC interactions. These effects are accomplished without any significant alteration of the docking orientation or the footprint of the TCR on the QL9- ${ }^{\mathrm{d}}$ ligand. Subtle changes in the TCRs can also have a very significant effect on the fine specificity of the interactions, but the receptors retained biological activity as long as they were above a particular binding threshold.

\section{Supplementary Material}

Refer to Web version on PubMed Central for supplementary material.

\section{Acknowledgements}

We thank the University of Illinois Immunological Resource Center for assistance with SPR measurements.

\section{References}

1. Rudolph MG, Stanfield RL, Wilson IA. How TCRs bind MHCs, peptides, and coreceptors. Annu Rev Immunol 2006;24:419-466. [PubMed: 16551255]

2. Garcia KC, Adams EJ. How the T cell receptor sees antigen-a structural view. Cell 2005;122:333336. [PubMed: 16096054]

3. Manning TC, Schlueter CJ, Brodnicki TC, Parke EA, Speir JA, Garcia KC, Teyton L, Wilson IA, Kranz DM. Alanine scanning mutagenesis of an alphabeta T cell receptor: mapping the energy of antigen recognition. Immunity 1998;8:413-425. [PubMed: 9586632]

4. Borg NA, Ely LK, Beddoe T, Macdonald WA, Reid HH, Clements CS, Purcell AW, Kjer-Nielsen L, Miles JJ, Burrows SR, McCluskey J, Rossjohn J. The CDR3 regions of an immunodominant T cell receptor dictate the "energetic landscape" of peptide-MHC recognition. Nat Immunol 2005;6:171180. [PubMed: 15640805]

5. Mason D. A very high level of crossreactivity is an essential feature of the T-cell receptor. Immunol Today 1998;19:395-404. [PubMed: 9745202]

6. Garcia KC, Degano M, Pease LR, Huang M, Peterson PA, Teyton L, Wilson IA. Structural basis of plasticity in T cell receptor recognition of a self peptide-MHC antigen. Science 1998;279:1166-1172. [PubMed: 9469799]

7. Reiser JB, Darnault C, Gregoire C, Mosser T, Mazza G, Kearney A, van der Merwe PA, FontecillaCamps JC, Housset D, Malissen B. CDR3 loop flexibility contributes to the degeneracy of TCR recognition. Nat Immunol 2003;4:241-247. [PubMed: 12563259]

8. Gagnon SJ, Borbulevych OY, Davis-Harrison RL, Baxter TK, Clemens JR, Armstrong KM, Turner RV, Damirjian M, Biddison WE, Baker BM. Unraveling a hotspot for TCR recognition on HLA-A2: evidence against the existence of peptide-independent TCR binding determinants. J Mol Biol 2005;353:556-573. [PubMed: 16197958]

9. Willcox BE, Gao GF, Wyer JR, Ladbury JE, Bell JI, Jakobsen BK, van der Merwe PA. TCR binding to peptide-MHC stabilizes a flexible recognition interface. Immunity 1999;10:357-365. [PubMed: 10204491]

10. Ishizuka J, Stewart-Jones GB, van der Merwe A, Bell JI, McMichael AJ, Jones EY. The structural dynamics and energetics of an immunodominant $\mathrm{T}$ cell receptor are programmed by its Vbeta domain. Immunity 2008;28:171-182. [PubMed: 18275829]

11. Boniface JJ, Reich Z, Lyons DS, Davis MM. Thermodynamics of T cell receptor binding to peptideMHC: evidence for a general mechanism of molecular scanning. Proc Natl Acad Sci USA 1999;96:11446-11451. [PubMed: 10500196]

12. Garcia KC, Radu CG, Ho J, Ober RJ, Ward ES. Kinetics and thermodynamics of T cell receptorautoantigen interactions in murine experimental autoimmune encephalomyelitis. Proc Natl Acad Sci USA 2001;98:6818-6823. [PubMed: 11391002] 
13. Anikeeva N, Lebedeva T, Krogsgaard M, Tetin SY, Martinez-Hackert E, Kalams SA, Davis MM, Sykulev Y. Distinct molecular mechanisms account for the specificity of two different T-cell receptors. Biochemistry 2003;42:4709-4716. [PubMed: 12705834]

14. Mazza C, Auphan-Anezin N, Gregoire C, Guimezanes A, Kellenberger C, Roussel A, Kearney A, van der Merwe PA, Schmitt-Verhulst AM, Malissen B. How much can a T-cell antigen receptor adapt to structurally distinct antigenic peptides? EMBO J 2007;26:1972-1983. [PubMed: 17363906]

15. Ely LK, Beddoe T, Clements CS, Matthews JM, Purcell AW, Kjer-Nielsen L, McCluskey J, Rossjohn J. Disparate thermodynamics governing T cell receptor-MHC-I interactions implicate extrinsic factors in guiding MHC restriction. Proc Natl Acad Sci USA 2006;103:6641-6646. [PubMed: 16617112]

16. Gakamsky DM, Lewitzki E, Grell E, Saulquin X, Malissen B, Montero-Julian F, Bonneville M, Pecht I. Kinetic evidence for a ligand-binding-induced conformational transition in the T cell receptor. Proc Natl Acad Sci USA 2007;104:16639-16644. [PubMed: 17921250]

17. Tynan FE, Reid HH, Kjer-Nielsen L, Miles JJ, Wilce MC, Kostenko L, Borg NA, Williamson NA, Beddoe T, Purcell AW, Burrows SR, McCluskey J, Rossjohn J. A T cell receptor flattens a bulged antigenic peptide presented by a major histocompatibility complex class I molecule. Nat Immunol 2007;8:268-276. [PubMed: 17259989]

18. Lee JK, Stewart-Jones G, Dong T, Harlos K, Di Gleria K, Dorrell L, Douek DC, van der Merwe PA, Jones EY, McMichael AJ. T cell cross-reactivity and conformational changes during TCR engagement. J Exp Med 2004;200:1455-1466. [PubMed: 15583017]

19. Kranz DM, Sherman DH, Sitkovsky MV, Pasternack MS, Eisen HN. Immunoprecipitation of cell surface structures of cloned cytotoxic T lymphocytes by clone-specific antisera. Proc Natl Acad Sci USA 1984;81:573-577. [PubMed: 6607474]

20. Udaka K, Tsomides TJ, Walden P, Fukusen N, Eisen HN. A ubiquitous protein is the source of naturally occurring peptides that are recognized by a CD8+ T-cell clone. Proc Natl Acad Sci USA 1993;90:11272-11276. [PubMed: 8248240]

21. Sykulev Y, Brunmark A, Tsomides TJ, Kageyama S, Jackson M, Peterson PA, Eisen HN. Highaffinity reactions between antigen-specific T-cell receptors and peptides associated with allogeneic and syngeneic major histocompatibility complex class I proteins. Proc Natl Acad Sci USA 1994;91:11487-11491. [PubMed: 7972089]

22. Garcia KC, Tallquist MD, Pease LR, Brunmark A, Scott CA, Degano M, Stura EA, Peterson PA, Wilson IA, Teyton L. Alphabeta T cell receptor interactions with syngeneic and allogeneic ligands: affinity measurements and crystallization. Proc Natl Acad Sci USA 1997;94:13838-13843. [PubMed: 9391114]

23. Holler PD, Holman PO, Shusta EV, O'Herrin S, Wittrup KD, Kranz DM. In vitro evolution of a T cell receptor with high affinity for peptide/MHC. Proc Natl Acad Sci USA 2000;97:5387-5392. [PubMed: 10779548]

24. Holler PD, Chlewicki LK, Kranz DM. TCRs with high affinity for foreign pMHC show self-reactivity. Nat Immunol 2003;4:55-62. [PubMed: 12469116]

25. Chlewicki LK, Holler PD, Monti BC, Clutter MR, Kranz DM. High-affinity, peptide-specific T cell receptors can be generated by mutations in CDR1, CDR2 or CDR3. J Mol Biol 2005;346:223-239. [PubMed: 15663940]

26. Colf LA, Bankovich AJ, Hanick NA, Bowerman NA, Jones LL, Kranz DM, Garcia KC. How a single T cell receptor recognizes both self and foreign MHC. Cell 2007;129:135-146. [PubMed: 17418792]

27. Jones LL, Colf LA, Stone JD, Garcia KC, Kranz DM. Distinct CDR3 conformations in T cell receptors determine the level of cross-reactivity for diverse antigens, but not the docking orientation. J Immunol 2008;181:6255-6264. [PubMed: 18941216]

28. Shusta EV, Holler PD, Kieke MC, Kranz DM, Wittrup KD. Directed evolution of a stable scaffold for T-cell receptor engineering. Nat Biotechnol 2000;18:754-759. [PubMed: 10888844]

29. Maynard J, Adams EJ, Krogsgaard M, Petersson K, Liu CW, Garcia KC. High-level bacterial secretion of single-chain alphabeta T-cell receptors. J Immunol Methods 2005;306:51-67. [PubMed: 16198365] 
30. Jones LL, Brophy SE, Bankovich AJ, Colf LA, Hanick NA, Garcia KC, Kranz DM. Engineering and characterization of a stabilized alpha1/alpha2 module of the class I major histocompatibility complex product Ld. J Biol Chem 2006;281:25734-25744. [PubMed: 16815841]

31. Holler PD, Lim AR, Cho BK, Rund LA, Kranz DM. CD8(-) T cell transfectants that express a high affinity T cell receptor exhibit enhanced peptide-dependent activation. J Exp Med 2001;194:10431052. [PubMed: 11602635]

32. Otwinowski Z, Minor W. Processing of X-ray diffraction data collected in oscillation mode. Methods Enzymol 1997;276:307-326.

33. Adams PD, Grosse-Kunstleve RW, Hung LW, Ioerger TR, McCoy AJ, Moriarty NW, Read RJ, Sacchettini JC, Sauter NK, Terwilliger TC. PHENIX: building new software for automated crystallographic structure determination. Acta Crystallogr, Sect D: Biol Crystallogr 2002;58:19481954. [PubMed: 12393927]

34. Jones TA, Zou JY, Cowan SW, Kjeldgaard M. Improved methods for building protein models in electron density maps and the location of errors in these models. Acta Crystallogr 1991;A47(Part 2): 110-119.

35. Emsley P, Cowtan K. Coot: model-building tools for molecular graphics. Acta Crystallogr, Sect D: Biol Crystallogr 2004;60:2126-2132. [PubMed: 15572765]

36. Brunger AT, Adams PD, Clore GM, DeLano WL, Gros P, Grosse-Kunstleve RW, Jiang JS, Kuszewski J, Nilges M, Pannu NS, Read RJ, Rice LM, Simonson T, Warren GL. Crystallography \& NMR system: A new software suite for macromolecular structure determination. Acta Crystallogr, Sect D: Biol Crystallogr 1998;54:905-921. [PubMed: 9757107]

37. Schlueter CJ, Manning TC, Schodin BA, Kranz DM. A residue in the center of peptide QL9 affects binding to both Ld and the T cell receptor. J Immunol 1996;157:4478-4485. [PubMed: 8906825]

38. Dunn SM, Rizkallah PJ, Baston E, Mahon T, Cameron B, Moysey R, Gao F, Sami M, Boulter J, Li Y, Jakobsen BK. Directed evolution of human T cell receptor CDR2 residues by phage display dramatically enhances affinity for cognate peptide-MHC without increasing apparent crossreactivity. Protein Sci 2006;15:710-721. [PubMed: 16600963]

39. Cho BK, Lian KC, Lee P, Brunmark A, McKinley C, Chen J, Kranz DM, Eisen HN. Differences in antigen recognition and cytolytic activity of CD8(+) and CD8(-) T cells that express the same antigen-specific receptor. Proc Natl Acad Sci USA 2001;98:1723-1727. [PubMed: 11172018]

40. Sykulev Y, Brunmark A, Jackson M, Cohen RJ, Peterson PA, Eisen HN. Kinetics and affinity of reactions between an antigen-specific $\mathrm{T}$ cell receptor and peptide-MHC complexes. Immunity 1994;1:15-22. [PubMed: 7889394]

41. Soo Hoo WF, Kranz DM. Role of CD8 in staphylococcal enterotoxin B-mediated lysis by cytotoxic T lymphocytes. J Immunol 1993;150:4331-4337. [PubMed: 8482838]

42. Daniels MA, Jameson SC. Critical role for CD8 in T cell receptor binding and activation by peptide/ major histocompatibility complex multimers. J Exp Med 2000;191:335-346. [PubMed: 10637277]

43. Kalergis AM, Boucheron N, Doucey MA, Palmieri E, Goyarts EC, Vegh Z, Luescher IF, Nathenson SG. Efficient T cell activation requires an optimal dwell-time of interaction between the TCR and the pMHC complex. Nat Immunol 2001;2:229-234. [PubMed: 11224522]

44. Holler PD, Kranz DM. Quantitative analysis of the contribution of TCR/pepMHC affinity and CD8 to T cell activation. Immunity 2003;18:255-264. [PubMed: 12594952]

45. Krogsgaard M, Prado N, Adams EJ, He XL, Chow DC, Wilson DB, Garcia KC, Davis MM. Evidence that structural rearrangements and/or flexibility during TCR binding can contribute to T cell activation. Mol Cell 2003;12:1367-1378. [PubMed: 14690592]

46. Armstrong KM, Piepenbrink KH, Baker BM. Conformational changes and flexibility in T-cell receptor recognition of peptide-MHC complexes. Biochem J 2008;415:183-196. [PubMed: 18800968]

47. Davis-Harrison RL, Armstrong KM, Baker BM. Two different T cell receptors use different thermodynamic strategies to recognize the same peptide/MHC ligand. J Mol Biol 2005;346:533550. [PubMed: 15670602]

48. Huseby ES, Crawford F, White J, Marrack P, Kappler JW. Interface-disrupting amino acids establish specificity between $\mathrm{T}$ cell receptors and complexes of major histocompatibility complex and peptide. Nat Immunol 2006;7:1191-1199. [PubMed: 17041605] 
49. Sundberg EJ, Urrutia M, Braden BC, Isern J, Tsuchiya D, Fields BA, Malchiodi EL, Tormo J, Schwarz FP, Mariuzza RA. Estimation of the hydrophobic effect in an antigen-antibody protein-protein interface. Biochemistry 2000;39:15375-15387. [PubMed: 11112523] 


\section{A $\cdot$ CDR1 $\beta$}

$\begin{array}{ll}\text { wt } & 26 \text { TNNHNNM } \\ \text { 1 } 3 \text {-m3 } & \text { TNG }\end{array}$

- CDR2 $\alpha$

wt $\quad{ }^{48} \mathrm{KYYSGDPV}^{55}$

2 $\alpha-m 1$ KYVRGSSV

- $\operatorname{CDR3} \alpha$

wt ${ }^{98}$ SGFASAL 104

3 $\alpha-m 6$ SHQGRYL

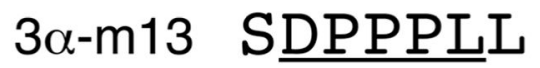

- CDR3 $\beta$

wt ${ }^{94}$ GGGGTLY$^{101}$

3ß-m4 GFGGELY

B
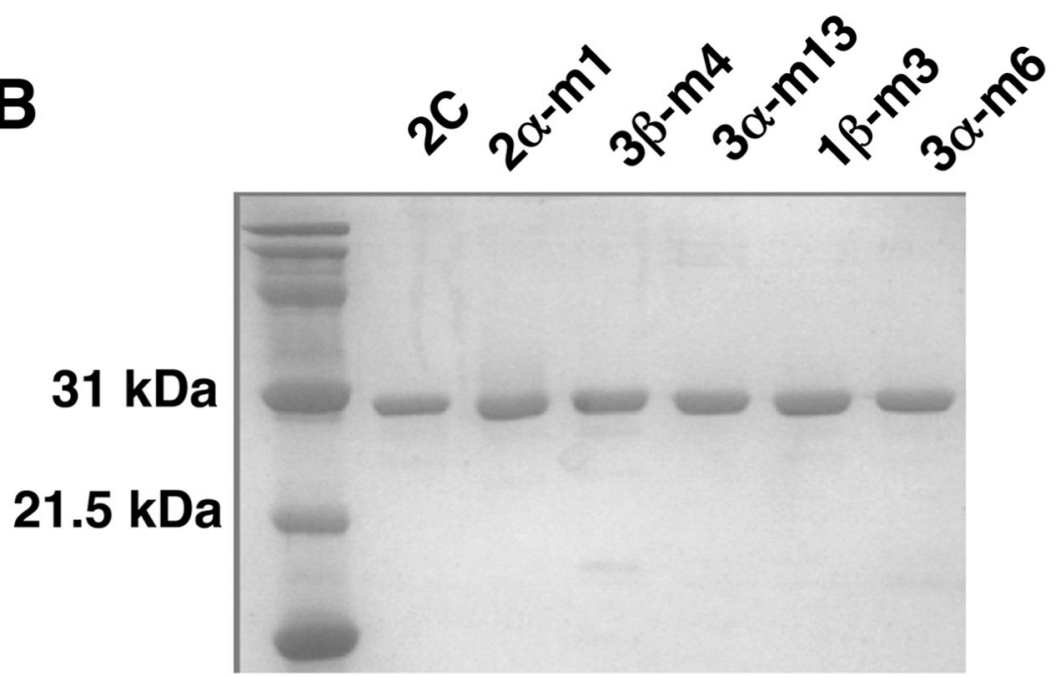

Figure 1.

Summary of high-affinity mutant TCRs. (A) CDR mutations in various high-affinity 2C TCR mutants. The sequence of individual CDR loops in the wild-type $2 \mathrm{C}$ receptor are shown, with the sequence and name of any mutants isolated from degenerate libraries within the indicated CDR listed below. (B) SDS-PAGE showing purified scTCRs used in thermodynamic and kinetic studies. Each lane was loaded with $2 \mu \mathrm{g}$ of purified protein. All scTCRs are near 30 $\mathrm{kDa}$, as indicated by the molecular mass marker. 
A
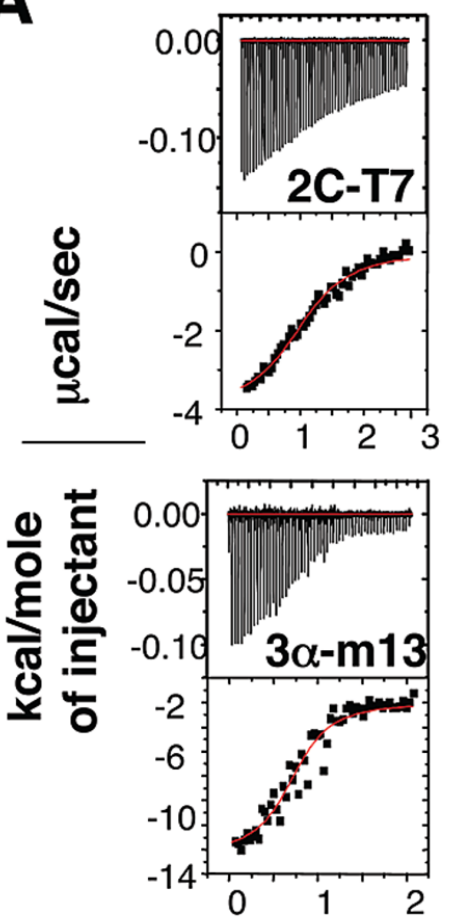

Time (min)
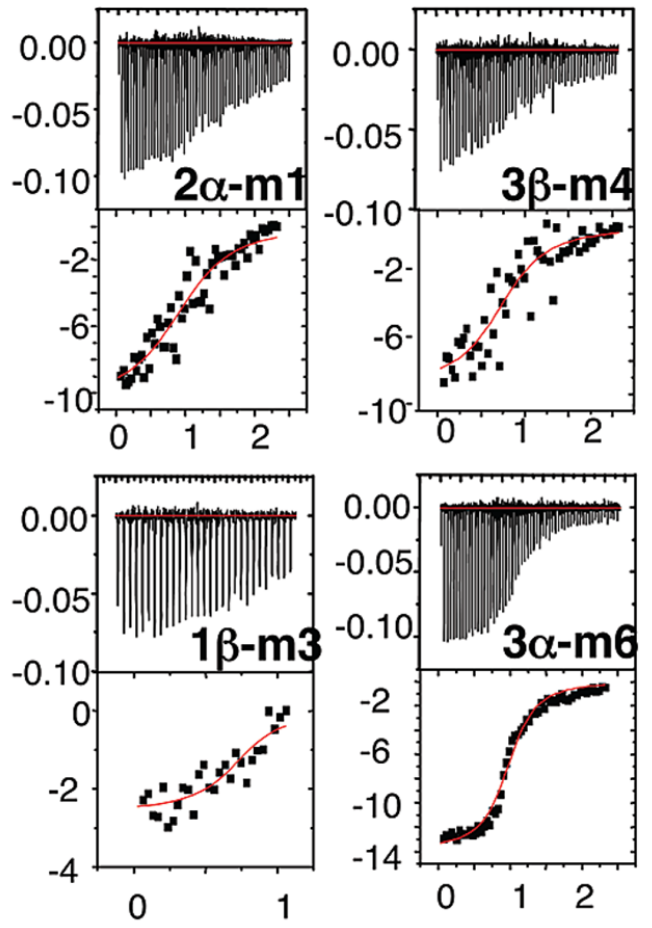

Molar Ratio

B

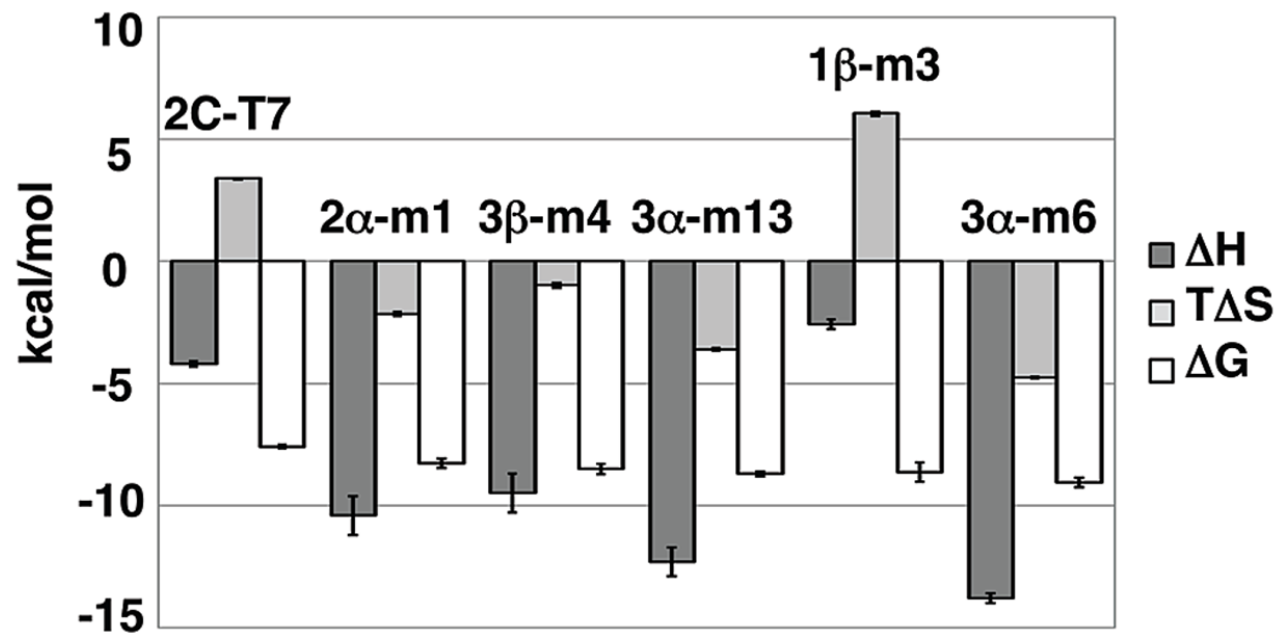

Figure 2.

Thermodynamics of high-affinity scTCR binding to QL9- ${ }^{\mathrm{d}}$. (A) Isothermal titration calorimetry (ITC) curves of 2C and high-affinity scTCRs titrated with QL9-L ${ }^{\mathrm{d}}$. (B) Summary of thermodynamic binding parameters associated with high-affinity scTCR/QL9-L ${ }^{\mathrm{d}}$ interactions. The values for $\Delta G$ (solid white bars), $\Delta H$ (dark gray bars), and $T \Delta S$ (light gray bars) for all interactions at $20^{\circ} \mathrm{C}$ are shown in $\mathrm{kcal} / \mathrm{mol} . \Delta H$ and was determined by ITC, and $\Delta G$ and $T \Delta S$ were calculated as described in the Experimental Procedures section. Error bars of $\Delta H$ represent the standard deviation over two or more independent experiments. Error bars for $\Delta G$ and $T \Delta S$ indicate mathematically propagated error, based on error in the measured $\Delta H$ and $K$ parameters. 
QL9-Ld
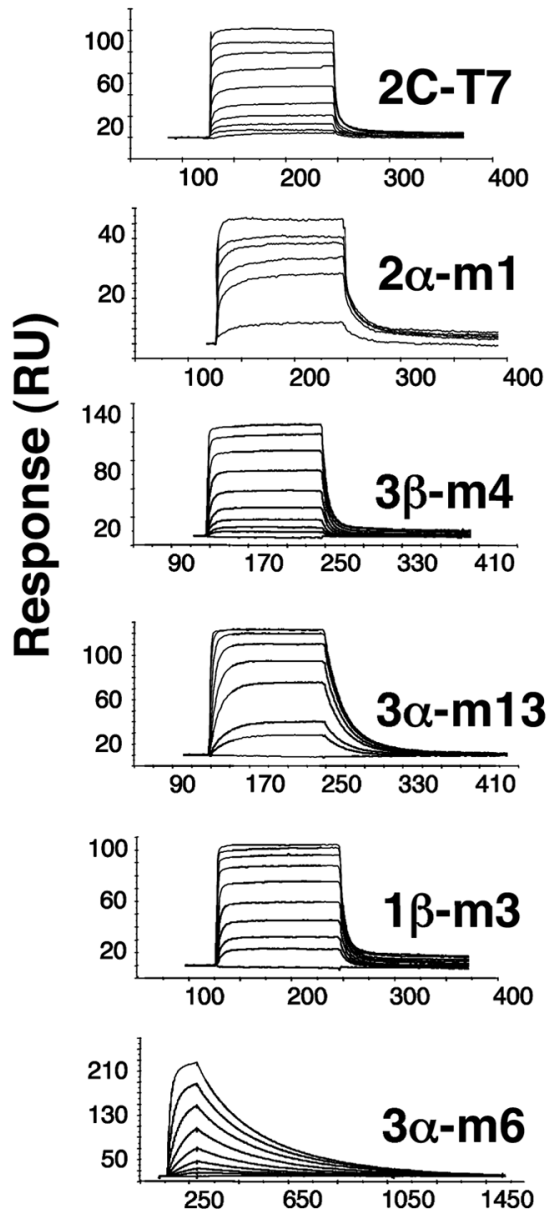

QL9 Y5-Ld
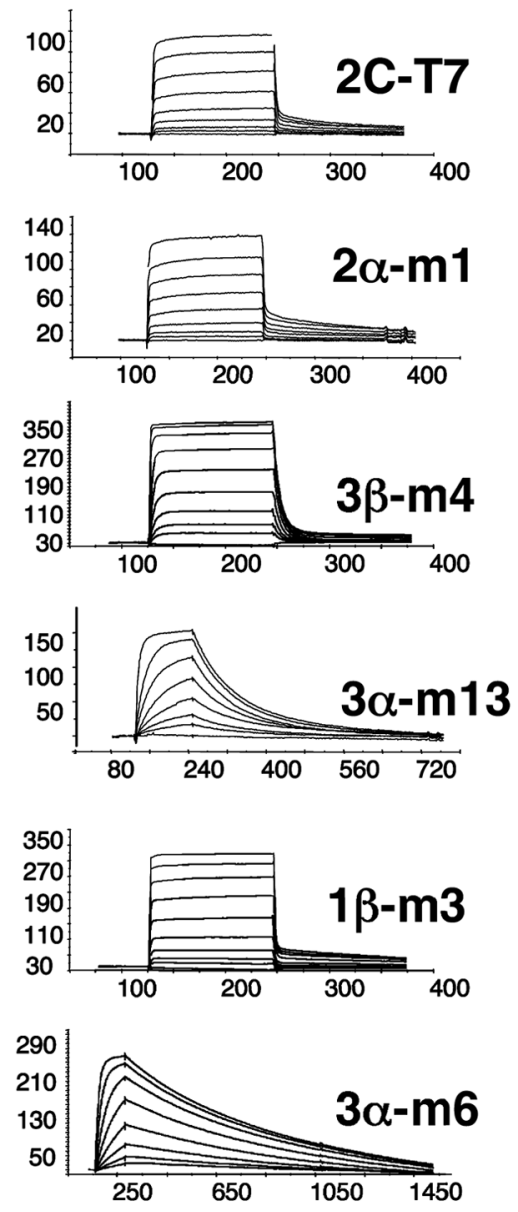

Time (s)

Figure 3.

Analysis of high-affinity scTCR binding to QL9-L ${ }^{\mathrm{d}}$ and altered peptide ligand QL9-Y5-L ${ }^{\mathrm{d}}$. Surface plasmon resonance (SPR) traces of high-affinity scTCR binding to immobilized QL9$\mathrm{L}^{\mathrm{d}}$ (left) and QL9-Y5-L (right). Biotinylated QL9-L ${ }^{\mathrm{d}}-\mathrm{m} 31$ or QL9-Y5-L ${ }^{\mathrm{d}}-\mathrm{m} 31$ was immobilized on a streptavidin sensor chip surface (BIAcore) at 450-500 response units (RU). Soluble scTCRs were flowed over the surface at a flow rate of $30 \mu \mathrm{L} / \mathrm{min}$ at varying concentrations, depending on the affinity of the interaction. From top to bottom on immobilized QL9-Ld: [2C-T7], 20, 10, 5, 2.5, 1.25, 0.625, 0.313, 0.156, and 0.078 $\mu \mathrm{M}$; [2 $\alpha-\mathrm{m} 1], 10,5,2.5$, $1.25,0.625$, and $0.078 \mu \mathrm{M}$; [3 $\beta-\mathrm{m} 4], 3.8,1.9,0.96,0.48,0.24,0.12,0.06,0.03$, and $0.015 \mu \mathrm{M}$;

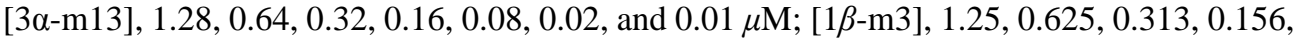

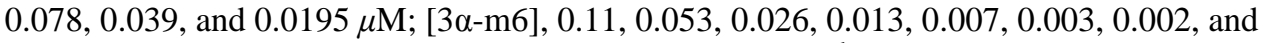
$0.0008 \mu \mathrm{M}$. From top to bottom on immobilized QL9-Y5-Ld: [2C-T7], 20, 10, 5, 2.5, 1.25 , $0.625,0.313,0.156$, and $0.078 \mu \mathrm{M}$; $[2 \alpha-\mathrm{m} 1], 5,2.5,1.25,0.63,0.31,0.16,0.08$, and $0.04 \mu \mathrm{M}$;

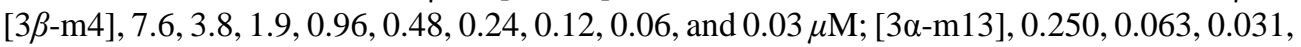
$0.016,0.008,0.004$, and $0.002 \mu \mathrm{M}$; $[1 \beta-\mathrm{m} 3], 5,2.5,1.25,0.63,0.31,0.16,0.08$, and $0.04 \mu \mathrm{M}$; [3 $\alpha$-m6], 0.105, 0.053, 0.026, 0.013, 0.007, 0.003, 0.002, and $0.0008 \mu \mathrm{M}$. To account for nonspecific interactions, binding to a biotin-blocked control surface was subtracted from the data. The bottom line in all traces represents an injection of buffer only. 


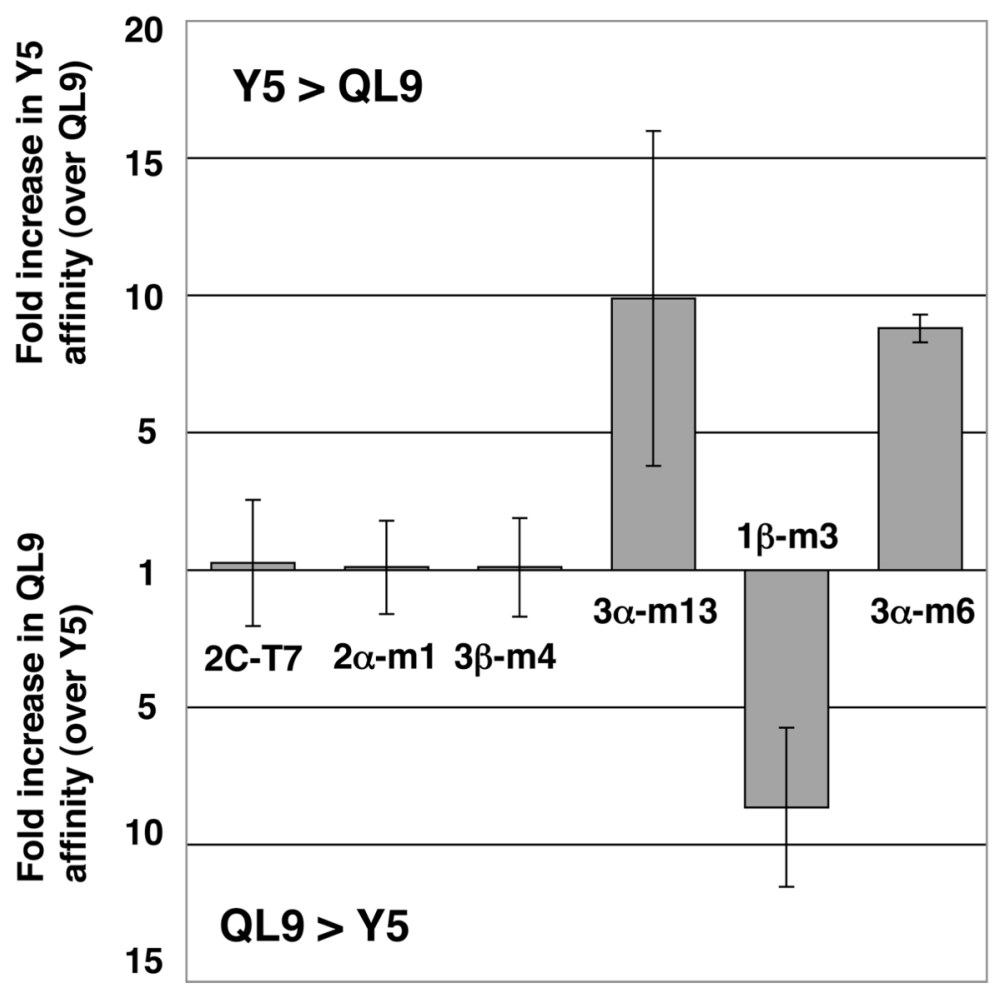

Figure 4.

Fine peptide specificity of high-affinity TCRs. Summary of kinetic binding affinities of scTCRs for QL9-L ${ }^{d}$ vs QL9-Y5-L ${ }^{d}$. For mutants with higher affinity for QL9-L ${ }^{d}$, fold difference in affinity was calculated as (affinity for QL9-Y5-L $\left.{ }^{\mathrm{d}}\right) /\left(\right.$ affinity for QL9-L ${ }^{\mathrm{d}}$ ), and bars pointing down indicate the magnitude of the affinity difference. For mutants with higher affinity for QL9-Y5-L ${ }^{d}$, fold difference in affinity was calculated as (affinity for QL9-L ${ }^{\mathrm{d}}$ )/ (affinity for QL9-Y5-L ${ }^{\mathrm{d}}$ ), and bars pointing up indicate the magnitude of the affinity difference. Error bars represent the standard deviation of two or more independent measurements of kinetic binding affinity by SPR. 

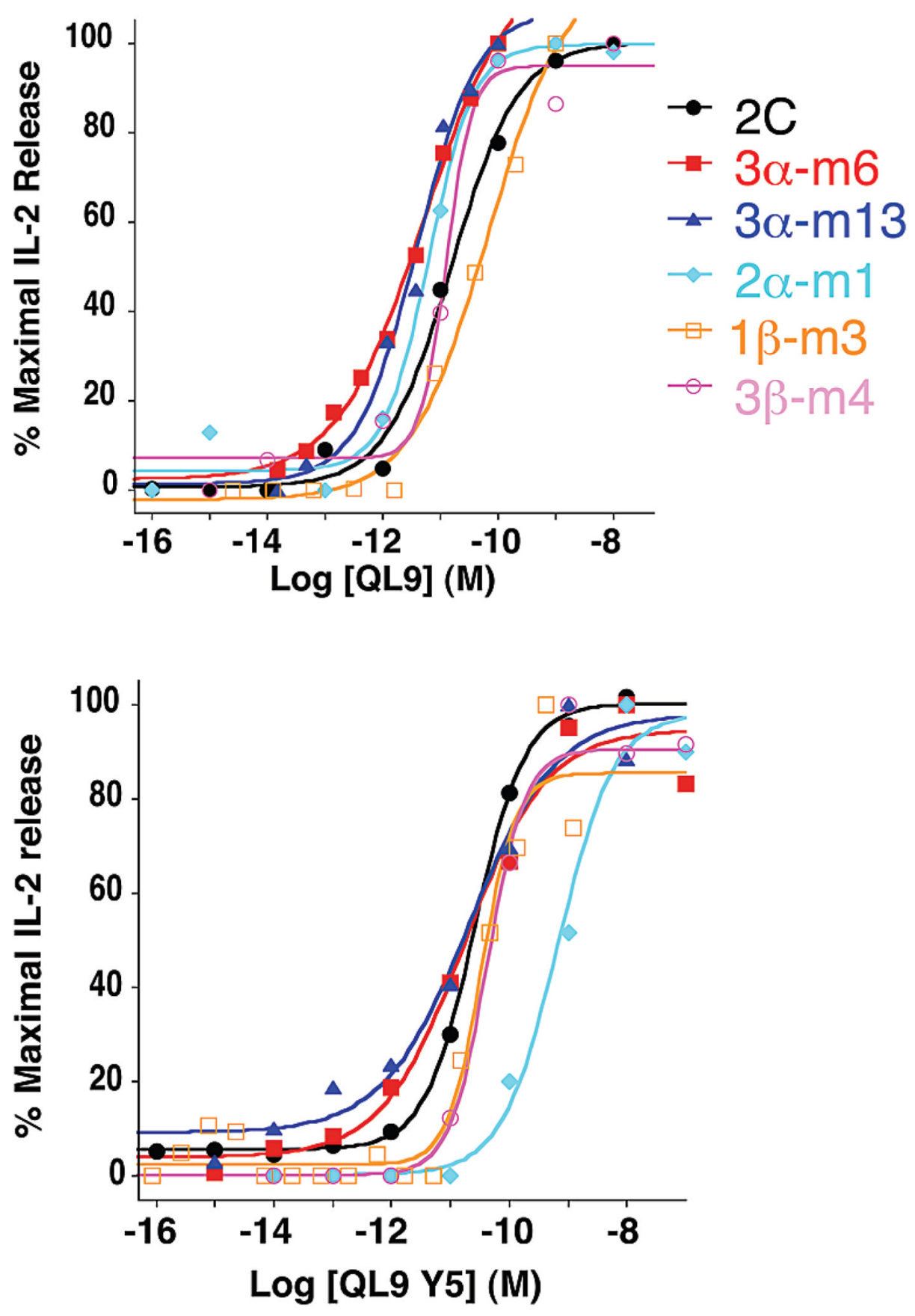

Figure 5.

Activation of high-affinity TCRs by QL9-L ${ }^{\mathrm{d}}$ and QL9-Y5- $\mathrm{L}^{\mathrm{d}}$ is CD8 independent. Percent maximal IL-2 release of CD8-negative TCR transfectants stimulated with (A) QL9-Ld or (B) QL9-Y5-L ${ }^{\mathrm{d}}$. Peptides were added to T2- $\mathrm{L}^{\mathrm{d}}$ cells, and an equal number of $\mathrm{T}$ cell transfectant cells were added. Cells were incubated for $24 \mathrm{~h}$ at $37{ }^{\circ} \mathrm{C}$, and supernatants were assayed for IL-2 using ELISA. $\%$ maximal IL-2 release $=\left[\left(\right.\right.$ sample $A_{450}-$ null peptide $\left.A_{450}\right) /\left(\mathrm{CD} 3 A_{450}\right.$ - null peptide $\left.\left.A_{450}\right)\right] \times 100$, where CD3 $A_{450}$ is the absorbance measured for cells stimulated with an anti-CD3 antibody and null peptide $A_{450}$ is the absorbance value for cells stimulated with a nullpeptide MCMV. 

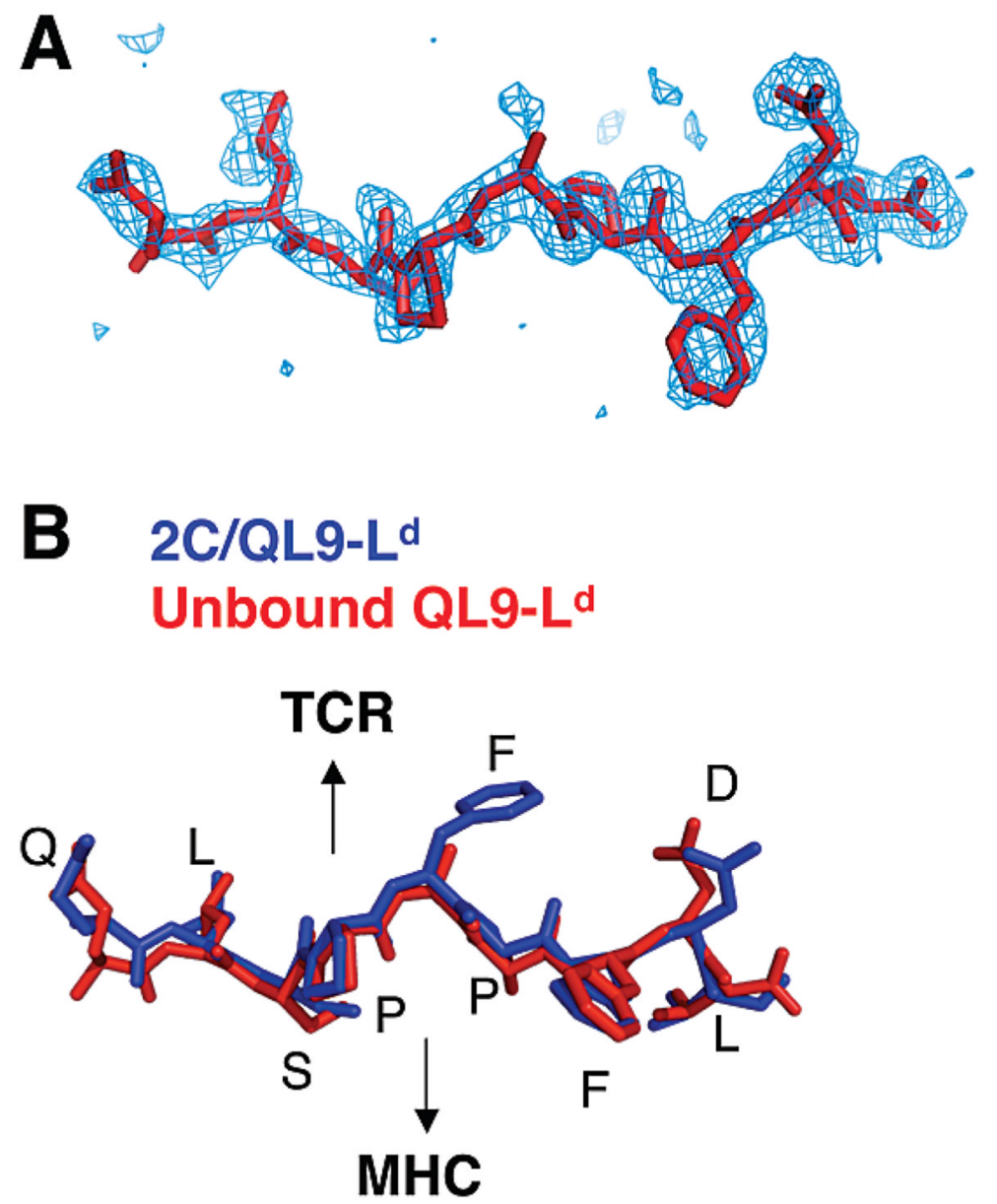

Figure 6.

QL9 peptide does not undergo large conformational adjustments upon TCR binding. (A) Conformation of QL9 peptide in the structure of the QL9-L ${ }^{\mathrm{d}}$ complex (red) with the simulated annealing omit map (cyan) contoured at 3.0 . Because there was no adequate electron density for the side chain of the phenylalanine at position 5, an alanine residue was modeled at position 5 in the structure. (B) Comparison of the QL9 peptide from the unliganded QL9-L ${ }^{\mathrm{d}}$ complex (red) and the 2C/QL9-L ${ }^{d}$ complex (blue). The positions of the TCR and MHC molecules are indicated with arrows. 


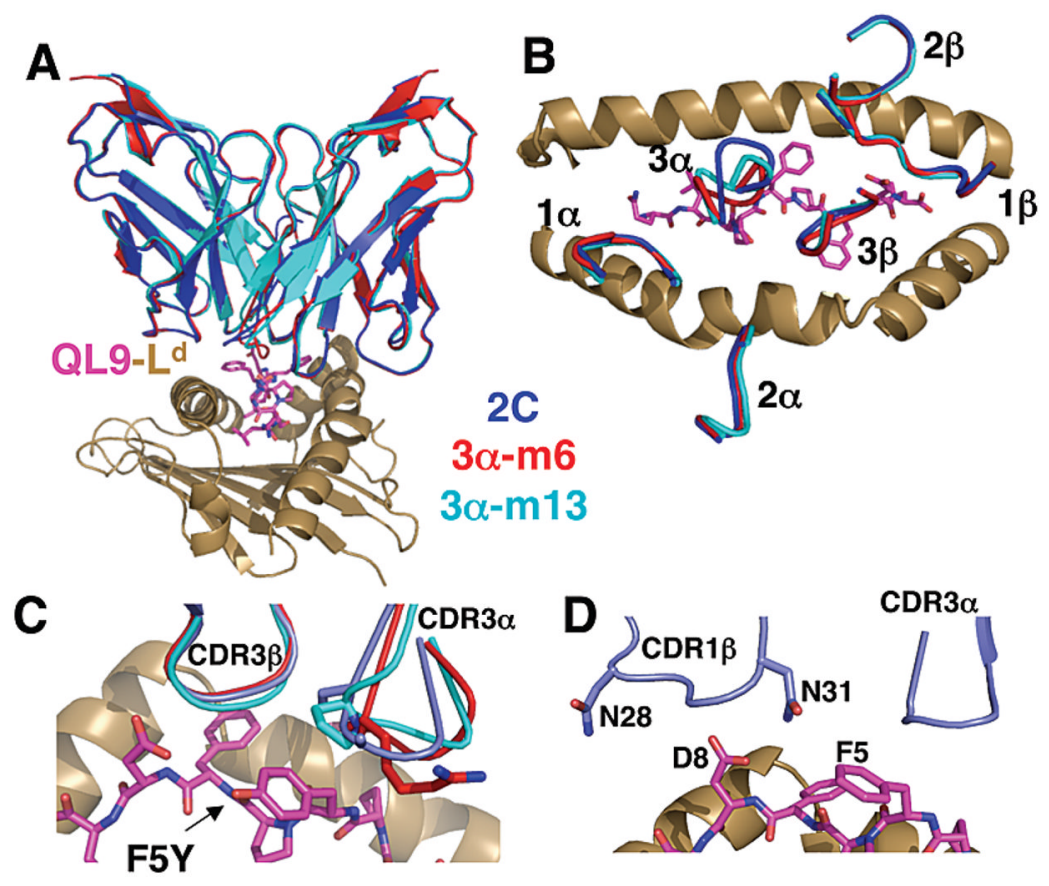

Figure 7.

Structures of TCR/QL9-Ld complexes. Superimposed structures of the 2C (blue), $3 \alpha-\mathrm{m} 6$ (red), and $3 \alpha-\mathrm{m} 13$ (cyan) TCRs in complex with QL9-L ${ }^{\mathrm{d}}$ show similarities in (A) the overall structure of the complexes and (B) the CDR conformations and docking orientation on QL9- $\mathrm{L}^{\mathrm{d}}$. (C) Close-up of CDR3 loops in the 2C and high-affinity complexes. Residue 102 in the CDR3 $\alpha$ is highlighted in all TCRs: S102 in 2C, R102 for m6, and P102 for m13. The phenylalanine residue at position 5 was replaced with a tyrosine using MacPyMOL software (DeLano Scientific LLC). (D) Close-up of the CDR1 $\beta$ loop in the 2C/QL9-Ld complex. The $2 \mathrm{C}$ TCR and the position of the two affinity mutations in the $1 \beta$-m3 mutant are shown (N28G and N31R) in blue. In all structures, QL9 is shown in magenta and $\mathrm{L}^{\mathrm{d}}$ is shown in brown. 


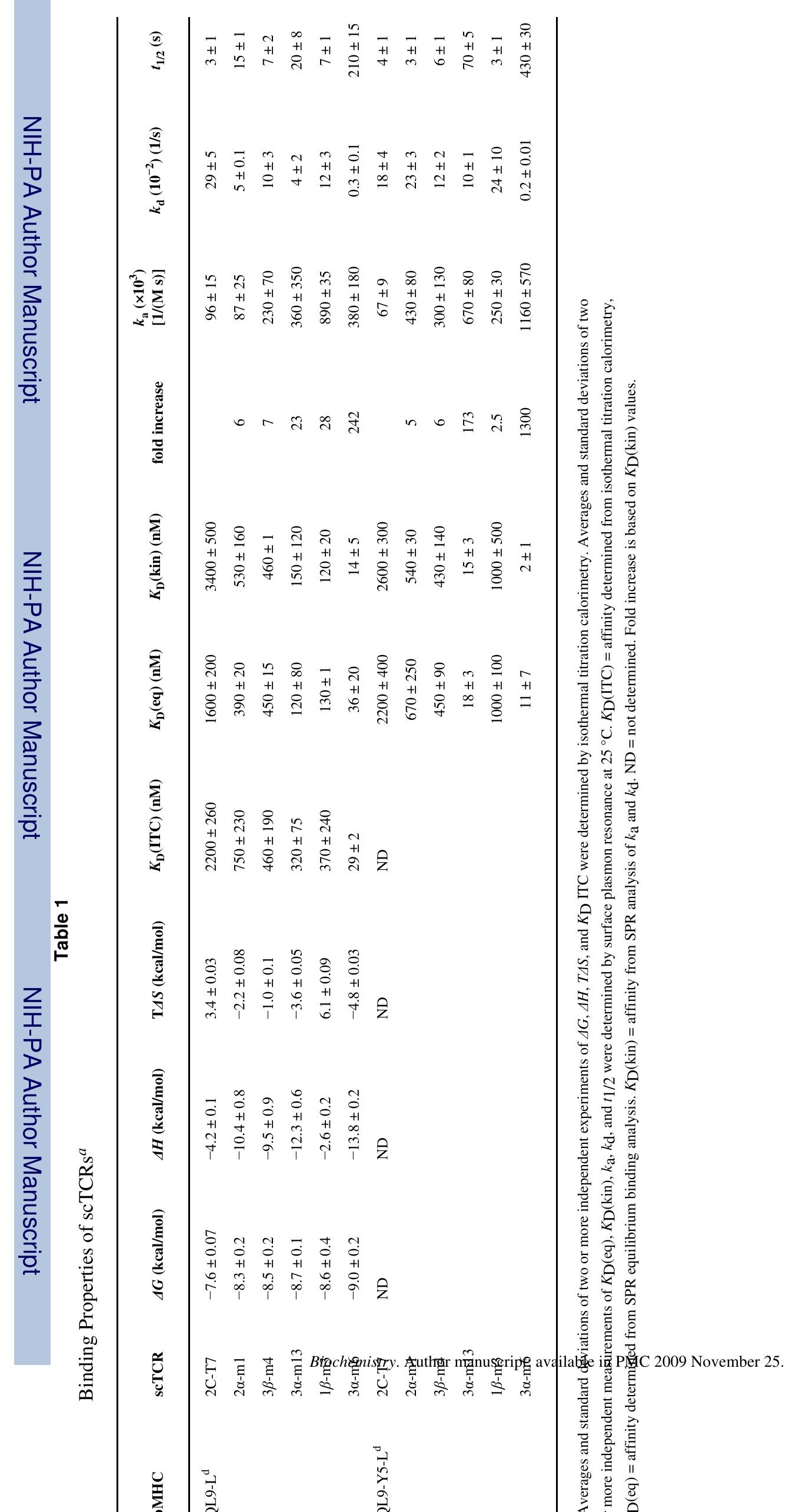


Table 2

Crystal and Refinement Data Statistics of QL9-L ${ }^{\mathrm{d}}-\mathrm{m} 31$

\begin{tabular}{|c|c|}
\hline \multicolumn{2}{|c|}{ Data Collection and Refinement Statistics } \\
\hline space group & $P 2_{1}$ \\
\hline \multicolumn{2}{|l|}{ unit cell } \\
\hline$a, b, c(\AA)$ & $47.2,74.3,52.3$ \\
\hline$\alpha, \beta, \gamma(\operatorname{deg})$ & $90.0,107.7,90.0$ \\
\hline resolution $(\AA)$ & $1.95(10-1.95)$ \\
\hline unique reflections & 24939 \\
\hline$R$-merge & $0.056(0.130)$ \\
\hline redundancy & $6.6(3.9)$ \\
\hline completeness $(\%)$ & $96.2(78.2)$ \\
\hline$R$-work $(\%)$ & 23.2 \\
\hline$R$-free $(\%)$ & 28.3 \\
\hline
\end{tabular}

